\title{
Noddy, a Mouse Harboring a Missense Mutation in Protocadherin-15, Reveals the Impact of Disrupting a Critical Interaction Site between Tip-Link Cadherins in Inner Ear Hair Cells
}

\author{
Ruishuang Geng, ${ }^{1}$ Marcos Sotomayor, ${ }^{2}$ Kimberly J. Kinder, ${ }^{1}$ Suhasini R. Gopal, ${ }^{1}$ John Gerka-Stuyt, ${ }^{1}$ Daniel H.-C. Chen, \\ Rachel E. Hardisty-Hughes, ${ }^{3}$ Greg Ball, ${ }^{3}$ Andy Parker, ${ }^{3}$ Rachelle Gaudet, ${ }^{4}$ David Furness, ${ }^{5}$ Steve D. Brown, ${ }^{3}$ \\ David P. Corey, ${ }^{2}$ and Kumar N. Alagramam ${ }^{1,6,7}$ \\ ${ }^{1}$ Otolaryngology Head \& Neck Surgery, University Hospitals Case Medical Center, Case Western Reserve University, Cleveland, Ohio 44106, ${ }^{2}$ Howard \\ Hughes Medical Institute and Department of Neurobiology, Harvard Medical School, Boston, Massachusetts 02115, ${ }^{3}$ MRC Mammalian Genetics Unit, \\ Harwell, OX11 0RD, United Kingdom, ${ }^{4}$ Department of Molecular and Cellular Biology, Harvard University, Boston, Massachusetts 02138, ${ }^{5}$ Institute for \\ Science and Technology in Medicine, School of Life Sciences, Keele University, Staffordshire, ST5 5BG, United Kingdom, and Departments of ${ }^{6}$ Genetics \\ and ${ }^{7}$ Neurosciences, Case Western Reserve University, Cleveland, Ohio 44106
}

In hair cells of the inner ear, sound or head movement increases tension in fine filaments termed tip links, which in turn convey force to mechanosensitive ion channels to open them. Tip links are formed by a tetramer of two cadherin proteins: protocadherin 15 (PCDH15) and cadherin 23 (CDH23), which have 11 and 27 extracellular cadherin (EC) repeats, respectively. Mutations in either protein cause inner ear disorders in mice and humans. We showed recently that these two cadherins bind tip-to-tip in a "handshake" mode that involves the EC1 and EC2 repeats of both proteins. However, a paucity of appropriate animal models has slowed our understanding both of the interaction and of how mutations of residues within the predicted interface compromise tip link integrity. Here, we present noddy, a new mouse model for hereditary deafness. Identified in a forward genetic screen, noddy homozygotes lackinner ear function. Mapping and sequencing showed that noddy mutant mice harbor an isoleucineto-asparagine (I108N) mutation in the EC1 repeat of PCDH15. Residue I108 interacts with CDH23 EC2 in the handshake and its mutation impairs the interaction in vitro. The noddy mutation allowed us to determine the consequences of blocking the handshake in vivo: tip link formation and bundle morphology are disrupted, and mechanotransduction channels fail to remain open at rest. These results offer new insights into the interaction between PCDH15 and CDH23 and help explain the etiology of human deafness linked to mutations in the tip-link interface.

\section{Introduction}

Hearing and balance depend on hair cells, the specialized mechanoreceptors of the inner ear that convert head movement or

Received Sept. 21, 2012; revised Dec. 23, 2012; accepted Jan. 21, 2013.

Author contributions: R. Geng, M.S., R. Gaudet, D.F., S.D.B., D.P.C., and K.N.A. designed research; R. Geng, M.S., K.J.K., S.R.G., J.G.-S., D.H.-C.C., R.E.H.-H., G.B., A.P., R. Gaudet, D.F., S.D.B., D.P.C., and K.N.A. performed research; R. Geng, M.S., K.J.K., S.R.G., J.G.-S., D.H.-C.C., R.E.H.-H., G.B., A.P., R. Gaudet, D.F., S.D.B., D.P.C., and K.N.A. analyzed data; R. Geng and K.N.A. wrote the paper.

This work was supported by the National Institutes of Health (R01-DC010816 to K.N.A.; R01 DC02281 to D.P.C.; RC2GM093307 to National Resource for Biomedical Supercomputing/Pittsburgh Supercomputing Center), the National Science Foundation through TeraGrid/XSEDE (TRACMCB080015), Deafness Research United Kingdom funds (D.F.), and the Medical Research Council, United Kingdom (S.D.B.). M.S. was a Howard Hughes Medical Institute Fellow of the Helen Hay Whitney Foundation and is supported by the National Institute on Deafness and Other Communication Disorders (K99DC012534). D.P.C. is an Investigator of the Howard Hughes Medical Institute. Simulations were performed at the Texas Advanced Computing Center-Ranger and Pittsburgh Supercomputing Center-Anton supercomputers. We thank Bruce Derfler for assistance with mutagenesis, Robert Powers and Monique Brewster for advice on circular dichroism and thermostability assays, Victoria D'Souza and members of her laboratory for advice on calorimetry, Sue Morse for maintenance of noddy colonies, and llya Litvak for initial work on the noddy project after the mice arrived at Case Western Reserve University.

The authors declare no competing financial interests.

Correspondence should be addressed to Dr. Kumar N. Alagramam, Otolaryngology Head \& Neck Surgery, University Hospitals Case Medical Center, Case Western Reserve University, Cleveland, 0H 44106. E-mail: kna3@case.edu. DOI:10.1523/JNEUROSCI.4514-12.2013

Copyright $\odot 2013$ the authors $\quad 0270-6474 / 13 / 334395-10 \$ 15.00 / 0$ sound into electrical stimuli (Gillespie and Muller, 2009). The mechanotransduction function of hair cells occurs within the sensory hair bundle; each bundle comprises 30-300 actin-based stereocilia coupled to one another by tip links, protein filaments that connect the tip of each stereocilium to the side of its tallest neighboring stereocilium (Pickles et al., 1984). When the hair bundle is deflected in the excitatory direction, tip links are tensioned and are thought to directly pull open mechanotransduction channels located at their lower ends (Beurg et al., 2009).

Immunocytochemical, structural, and genetic evidence indicates that each tip link is a tetramer of protocadherin 15 (PCDH15) and cadherin 23 (CDH23), two atypical cadherin superfamily members (Ahmed et al., 2006; Kazmierczak et al., 2007; Alagramam et al., 2011). Mutations in the genes encoding $\mathrm{PCDH} 15$ and $\mathrm{CDH} 23$ produce deafness and balance disorders in mice and humans (Alagramam et al., 2001a, 2001b; Ahmed et al., 2001; Di Palma et al., 2001; Bork et al., 2001). It is thought that PCDH15 and CDH23 form cis-homodimers, which interact in trans via their opposing $\mathrm{N}$ termini (Kazmierczak et al., 2007) to create a tip link that is $\sim 170 \mathrm{~nm}$ long under endolymph-like calcium levels (Furness et al., 2008). However, the structural and 
molecular properties of the tip-link complex are just beginning to come to light (Sotomayor et al., 2010, 2012; Elledge et al., 2010).

The amino acid sequence and crystal structure of extracellular cadherin repeats 1 and $2(\mathrm{EC} 1+\mathrm{EC} 2)$ of $\mathrm{CDH} 23$ and PCDH15 contain classic cadherin folds but also show important differences from classical cadherins. First, they lack the residues of classical cadherins, such as the conserved tryptophan at position 2 and its hydrophobic binding pocket in the partner EC1, which are involved in the $\beta$-strand swapping underlying EC1 to EC1 bonds in trans (Brasch et al., 2012). Second, both PCDH15 EC1 and $\mathrm{CDH} 23 \mathrm{EC} 1$ contain an elongated $\mathrm{N}$ terminus with polar residues (Sotomayor et al., 2010; Elledge et al., 2010). Therefore, cadherins that evolved to endure the strong mechanical forces produced by loud noise most likely use an interface that is different from classical cadherins. Indeed, crystal structures of EC1 and EC2 of PCDH15 and CDH23 show binding in an extended "handshake" mode that involves EC1 and EC2 repeats of both proteins (Sotomayor et al., 2012). Yet this model has not been confirmed by independent methods, and it is unclear how mutations of interface residues might affect the integrity of the tip link in vivo.

Here we report on a new $N$-ethyl- $N$-nitrosourea (ENU)induced mouse mutant, noddy, which harbors a missense mutation $(\mathrm{I} 108 \mathrm{~N})$ in PCDH15 EC1, the first reported missense mutation in the mouse Pcdh15. Circular dichroism spectra indicated that the mutation does not affect protein folding, but binding of PCDH15-CDH23 fragments in vitro is impaired by this mutation, as determined by isothermal titration calorimetry experiments. Thus, noddy mutant mice allowed us to determine the consequences of blocking the handshake interaction in vivo.

\section{Materials and Methods}

Experiments on mice were performed according to animal welfare guidelines at the Medical Research Council United Kingdom and Case Western Reserve University.

Chemical mutagenesis, functional studies, positional gene identification, bundle morphology evaluation, and scanning electron microscopy. Standard methods previously described include ENU recessive mutagenesis (Hardisty-Hughes et al., 2010), assessment of hearing using clickbox and ABR recording (Parker et al., 2010), and bundle morphology visualization (Alagramam et al., 2011). Sample preparation for scanning electron microscopy was performed using the osmium-thiocarbohydrazide impregnation method as described previously (Furness and Hackney, 1985), and the images were acquired using a Hitachi S4500 field emission scanning electron microscopy.

FM1-43 uptake assay. In brief, cochlear epithelium tissue was dissected from postnatal day $2(\mathrm{P} 2)$ mice and cultured $18-20 \mathrm{~h}(\mathrm{P} 3)$ at $37^{\circ} \mathrm{C}$ with $5 \% \mathrm{CO}_{2}$ and $95 \%$ humidity in MEM (Invitrogen) supplemented with $10 \%(\mathrm{v} / \mathrm{v}$ ) horse serum, $10 \mathrm{~mm}$ HEPES, and $10 \mu \mathrm{g} / \mathrm{ml}$ ampicillin. Coverslips with adherent cochlear cultures were washed once with HEPESbuffered (10 mM, pH 7.2) HBSS (HBHBSS), dipped for $10 \mathrm{~s}$ in HBHBSS containing $3 \mathrm{mM}$ FM1-43, and washed immediately three times in a large volume of HBHBSS ( $10 \mathrm{~s}$ for each wash). The coverslips were then placed on a glass slide and viewed with an upright microscope equipped with epifluorescence optics and FITC filters (488 nm excitation, $520 \mathrm{~nm}$ emission) using a $40 \times$ dry objective. Images were captured with focus plane below cuticular plates at fixed time points after a dye application using a 12-bit cooled CCD camera (Retiga Exi Aqua Blue; Q-Imaging). Differential Interference Contrast (DIC) images were also taken with focus on apical surface of hair cells.

Genotyping for the noddy mutation. The single nucleotide change in noddy results in the introduction of a new restriction site, MseI. The genotyping scheme exploits this change to distinguish wild-type from noddy allele. Genomic DNA ( $~ 500$ ng/reaction) was amplified under standard reaction conditions using Platinum TaqDNA polymerase (In- vitrogen) for 35 cycles $\left(94^{\circ} \mathrm{C}\right.$ for $20 \mathrm{~s}, 55^{\circ} \mathrm{C}$ for $30 \mathrm{~s}$, and $72^{\circ} \mathrm{C}$ for $30 \mathrm{~s}$ ). Primer pairs are as follows: forward primer, $5^{\prime}$-GTGTGTTGGTGTCTAAAACGATG-3'; and reverse primer, 5'-TCTTTTACCTCTAGGCACATTCG-3'. PCR product was digested with restriction enzyme MseI using a reaction condition suggested by the manufacturer (New England Biolabs). The products were resolved using agarose gel $(3 \% \mathrm{w} / \mathrm{v})$ electrophoresis.

Genotyping for the transgene in Pcdh1 $5^{T g 2742}$ mutation. Characterization of the transgene induced disabling mutation and phenotype in Pcdh15 ${ }^{T g 2742}$ mice has been described previously (Alagramam et al., 1999 and 2001). The transgene ( $\mathrm{Tg}$ ), a linear bacterial plasmid vector containing an ampicillin resistance gene and other sequences unrelated to mouse genome, was used in a forward genetic screen to generate insertional mutants and identify genes important for development. The Pcdh $15^{\text {Tg2 } 2742}$ mouse is one of the mutants that arose from that project (Alagramam et al., 1999). The transgene was used as a unique DNA marker to clone and characterize the mutant locus. The \#2742 was arbitrarily assigned and has no significance. More details about the insertional mutagenesis approach and insertional mutant $P c d h 15^{\text {Tg2 } 2742}$ were described previously(Woychik and Alagramam, 1998; Alagramam et al., 1999). The sequence of the transgene is unique and not contained in the genomic DNA of wild-type mice (Alagramam et al., 1999). Identification of the transgene was performed as follows. Genomic DNA ( $\sim 500 \mathrm{ng} /$ reaction) isolated from mice was amplified under standard reaction conditions using Platinum TaqDNA polymerase (Invitrogen) for 35 cycles of $94^{\circ} \mathrm{C}$ for $20 \mathrm{~s}, 55^{\circ} \mathrm{C}$ for $30 \mathrm{~s}$, and $72^{\circ} \mathrm{C}$ for $2 \mathrm{~min}$. A (forward) primer on the ampicillin gene $5^{\prime}$-ATAATACCGCGCCACATAGC-3' and a (reverse) primer on the human $\beta$ actin promoter $5^{\prime}$-CCCTGGCCTTGTATCTTTCA- $3^{\prime}$ were used in PCR to check for the presence of the transgene. The PCR product was resolved using agarose gel $(3 \% \mathrm{w} / \mathrm{v})$ electrophoresis.

Antibody and immunofluorescence. The anti-PCDH15 antibody PB811 was kindly provided by Dr. Bechara Kachar and has been described previously (Kazmierczak et al., 2007). For immunofluorescence, cochlear epithelium tissues were dissected from P2 mice and cultured for approximately $15 \mathrm{~h}$ at $37^{\circ} \mathrm{C}$ with $5 \% \mathrm{CO}_{2}$ and $95 \%$ humidity in MEM (Invitrogen) supplemented with $10 \%(\mathrm{v} / \mathrm{v})$ horse serum, $10 \mathrm{~mm}$ HEPES, and 10 $\mu \mathrm{g} / \mathrm{ml}$ ampicillin. The tissues were fixed in freshly prepared $4 \%(\mathrm{w} / \mathrm{v})$ paraformaldehyde for $1 \mathrm{~h}$ and then washed three times for $15 \mathrm{~min}$ in calcium-free buffer containing the following (in $\mathrm{mM}$ ): $140 \mathrm{NaCl}, 0.7$ $\mathrm{NaH}_{2} \mathrm{PO}_{4}, 5.8 \mathrm{KCl}, 2.2 \mathrm{MgCl}_{2}, 5$ EGTA, 5.6 D-glucose, and $10 \mathrm{HEPES}$, adjusted to $\mathrm{pH} 7.4$ with $\mathrm{NaOH}$, supplemented with MEM vitamins (1: $1000)$ and amino acids (1:500). The tissue was further incubated in calcium-free buffer at $4^{\circ} \mathrm{C}$ overnight and then incubated with antiPCDH15 antibody PB811 at $2 \mu \mathrm{g} / \mathrm{ml}$ in calcium-free buffer at room temperature for $1 \mathrm{~h}$. After three 15 -min washes with calcium-free buffer, the tissues were incubated with Alexa Fluor- 488 conjugated anti-rabbit antibody (1:500 dilution, Invitrogen) and Alexa Fluor-546 conjugated phalloidin (1:100 dilution, Invitrogen) in calcium-free buffer supplemented with $0.1 \%$ Triton X-100 at room temperature for $1 \mathrm{~h}$. After three 15 min washes, tissues were mounted on slides and imaged with a Leica confocal microscope.

Structural and biochemical analysis. Cloning, expression, and purification of mouse CDH23 and PCDH15 EC1 + EC2 were previously described (Sotomayor et al., 2010, 2012). The noddy I108N mutation in PCDH15 EC1 + EC2 was generated using the QuikChange Lightning mutagenesis kit (Stratagene) and verified by DNA sequencing. Size exclusion chromatography (SEC) experiments were done on a Superdex75 column (GE Healthcare). Circular dichroism (CD) spectra were recorded at $10^{\circ} \mathrm{C}$ using a $1 \mathrm{~mm}$-path-length cuvette on a Jasco J-815 spectrometer. Samples for CD were purified in $20 \mathrm{~mm}$ Tris $\mathrm{HCl}, \mathrm{pH} 8.0,100$ $\mathrm{mm} \mathrm{KCl}$, and $1 \mathrm{mM} \mathrm{CaCl}_{2}$, and concentrated to 3.46 (WT) and $3.13 \mu \mathrm{M}$ (I108N). Thermostability assays (Niesen et al., 2007) were performed in triplicate with protein samples at 0.329 (WT) and $0.292(\mathrm{I} 108 \mathrm{~N}) \mathrm{mg} / \mathrm{ml}$ in a white thin-walled PCR plate (50 $\mu$ l per sample) mixed with the SYPRO Orange dye (Invitrogen). Measurements used a Bio-Rad Opticon 2 Real-Time PCR detector (sample plate heated using $1^{\circ} \mathrm{C}$ steps and a holding time of $1 \mathrm{~min}$ ). Melting temperatures were estimated from the peak of the first derivative of the fluorescence. Isothermal titration calorimetry (ITC) experiments were performed using a MicroCal iTC $_{200}$ 
A

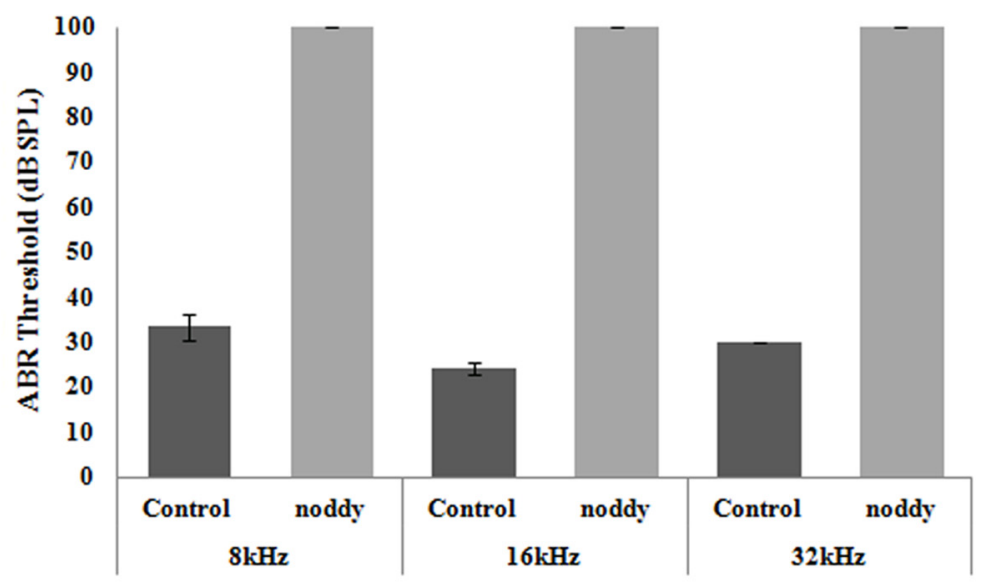

Stimulus frequency

B
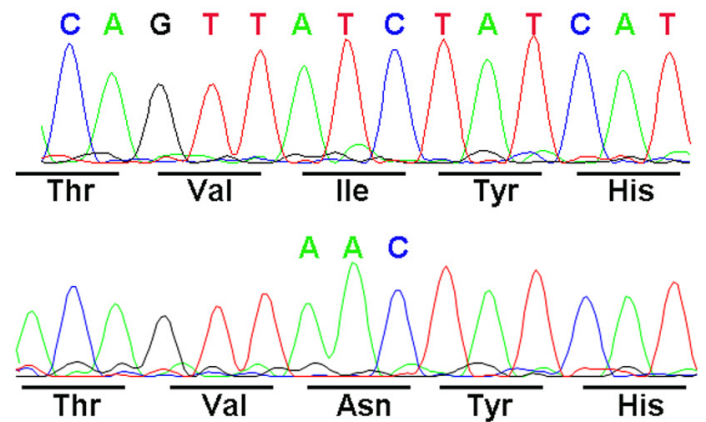

C

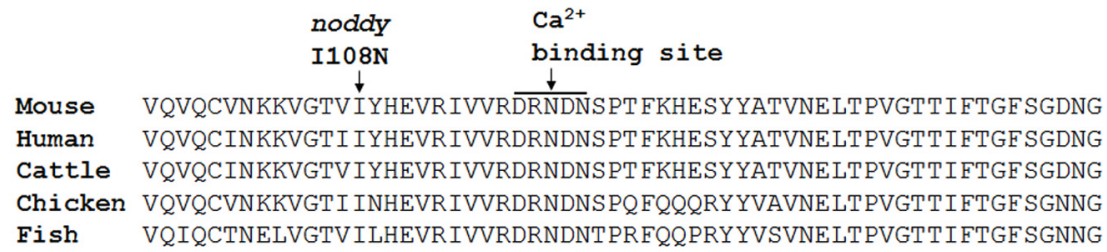

D $\quad 1108 \mathrm{~N}$

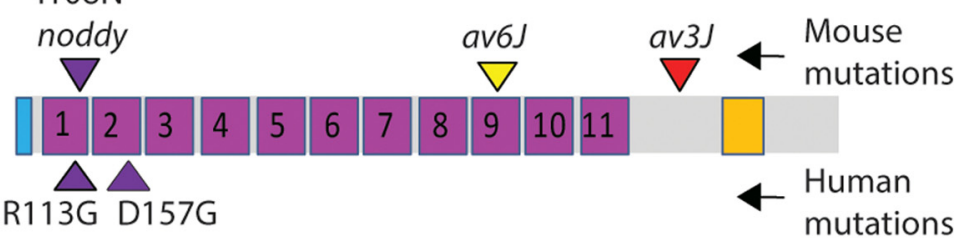

\= Signal sequence $\square=$ Cadherin domain $\square=$ Transmembrane domain

= Missense mutation $\nabla=$ Inframe deletion $\nabla=$ Stop mutation

Figure 1. Characterization of the noddy mice and localization of noddy mutation in PCDH15. A, Hearing loss in control and noddy mutant mice. Pure-tone-evoked ABR shows auditory thresholds for control $(+/ n)(n=3)$ and noddy $(n / n)(n=5)$ at P18. B, Sequence chromatogram from wild-type (top) and noddy mutant (bottom) mice reveals a T-to-A mutation in the exon coding for EC1 of PCDH15, resulting in an Ile-108-Asn substitution. C, The $1108 \mathrm{~N}$ substitution affects an amino acid that is conserved across species. D, Domain structure of PCDH15, indicating the $11 \mathrm{EC}$ repeats (purple squares). Missense mutations in the noddy mutant mice and human PCDH15 EC1 and EC2 are indicated. Other mutations in mouse PCDH15 referred to in this report (av3J and av6J) are also indicated in this diagram.

calorimeter with buffer-matched samples at $10^{\circ} \mathrm{C}(20 \mathrm{~mm}$ HEPES, $\mathrm{pH}$ 7.5, $150 \mathrm{~mm} \mathrm{KCl}, 1 \mathrm{~mm} \mathrm{CaCl}_{2}$ ). In all ITC experiments, a $0.5 \mu$ injection (disregarded in analysis) was followed by $142.48 \mu$ l injections of CDH23 $\mathrm{EC} 1+\mathrm{EC} 2(933 \mu \mathrm{M} ; \Delta t=3 \mathrm{~min}) \cdot \mathrm{PCDH} 15 \mathrm{EC} 1+\mathrm{EC} 2$ or PCDH15 EC1 + EC2 I108N $(107 \mu \mathrm{M})$ was placed in the sample cell. Protein concentra- tions were measured using absorbance at 280 $\mathrm{nm}$ and theoretical extinction coefficients.

Systems for molecular dynamics simulations were prepared with the Visual Molecular Dynamics software (Humphrey et al., 1996) as previously described (Sotomayor et al., 2012); the PCDH15 I108N mutation was generated in silico using the Visual Molecular Dynamics Mutator plugin. The simulations box comprised the complex of PCDH15 EC1 + EC2 I108N and CDH23 EC1 + EC2, water molecules, and ions $(108,687$ atoms total). A 1.1 ns equilibration of the mutant complex was performed with Nanoscale Molecular Dynamics (Phillips et al., 2005) and followed by $0.727 \mu$ s of dynamics using Anton (Shaw et al., 2010), with parameters as described previously (Sotomayor et al., 2012). The number of water molecules within $5 \AA$ of $\mathrm{I} 108$ and I108N C $\alpha$ atoms was monitored throughout trajectories of a $1-\mu$ s-long simulation of the wild-type complex (Sotomayor et al., 2012) and the 0.727- $\mu$ s-long simulation reported here. Molecular images were created with Visual Molecular Dynamics.

\section{Results}

\section{Generation and phenotype of noddy} mutant mice

From a recessive ENU mutagenesis screen undertaken at MRC Harwell, United Kingdom, we sought mice with hearing impairment and abnormal balance. One such line was identified by the lack of an auditory startle (Preyer) reflex to a "clickbox" ( $\sim 20 \mathrm{kHz}$ at $90 \mathrm{~dB}$ sound pressure level) at P30. It also showed head-bobbing, and so was named noddy. Auditory brainstem recordings (ABRs) confirmed deafness in noddy homozygotes as early as P18 (Fig. 1A), which fail to show a response to any of the stimulus frequencies at the highest stimulus level (100 dB SPL).

Wild-type siblings displayed controlled head and body movements indicative of normal balance function. In contrast, noddy homozygotes displayed head-bobbing and circling behavior, as early as 2-3 weeks of age, indicative of early-onset vestibular dysfunction. Noddy homozygotes were further evaluated for balance by a swim test. When placed in water, wild-type mice surfaced immediately and maintained a horizontal bodyline; they used their tail effectively to remain prone. In contrast, noddy homozygotes mice remained submerged, completely disoriented, turning and tumbling beneath the surface. The erratic head movements and disoriented swimming behavior indicate a lack of balance function in noddy homozygotes. Overall, noddy mutant mice lack inner ear function.

First reported missense mutation in mouse Pcdh15

The affected genomic locus was initially mapped using a panel of SNP markers selected from the Mouse Phenome Database (MPD) 
to a $45 \mathrm{Mb}$ interval on chromosome 10 . Fine mapping using additional SNP markers and larger numbers of affected noddy mutant mice reduced this to an $11.54 \mathrm{Mb}$ interval between SNPs rs13480628 (chromosome 10: 67238174) and rs13459122 (chromosome 10: 80795365) that contained $\sim 40$ genes. Among these genes was Pcdh15, which when mutated in mice causes early onset deaf/circling behavior (Alagramam et al., 2001a; Hampton et al., 2003; Washington et al., 2005), making it the best candidate to harbor the noddy mutation. Analysis of the entire coding sequence of Pcdh15 in noddy mutant mice compared with the coding sequence in the database (GenBank accession NM_0231153) revealed a point mutation, T822A, in exon 6 , which produces an Ile-to-Asn substitution at position 134 within the $\mathrm{PCDH} 15$ protein sequence (Fig. 1B). Counting from the first residue after the cleaved 26 amino acid signal sequence, we refer to this mutation as "I108N." Isoleucine at position 108 is highly conserved across species and is located in the PCDH15 EC1 domain (Fig. 1C,D).

To confirm that the newly defined mutation in noddy mutant mice is indeed associated with $P c d h 15$, we performed a classical complementation analysis. Mice homozygous for the noddy allele were crossed to mice heterozygous for the Pcdh15 ${ }^{\operatorname{Tg} 2742}$ allele, a previously reported allele of Pcdh15 (Alagramam et al., 2001a). Offspring with either normal or deafcircling behavior were obtained from these crosses. Whereas offspring with normal behavior carried one wild-type Pcdh15 allele and one noddy mutant allele, mice showing deaf-circling behavior showed the compound heterozygous genotype of noddy/ Tg2742 (Fig. 2). Lacking a wild-type allele at the Pcdh15 locus, mice with both the noddy mutant allele and the $\mathrm{Tg} 2742$ allele express the phenotype, unequivocally demonstrating by noncomplementation that the hair cell phenotype in the noddy mutant mice is caused by a mutation in Pcdh15 rather than in some other locus. Thus, this new mutation was designated Pcdh $15^{\text {noddy }}$. Although other mutations in the mouse PCDH15 sequence have been described (Alagramam et al., 2001a; Hampton et al., 2003; Washington et al., 2005; Zheng et al., 2006), this is the first report of a missense mutation in mouse PCDH15. Because the EC1 domain is involved in the PCDH15-CDH23 interaction according to current models of the tip link (Kazmierczak et al., 2007; Sotomayor et al., 2012), we decided to test the functional consequences of the noddy mutation in vitro and in vivo.

\section{PCDH15-I108N mutation impairs in vitro binding between PCDH15 and $\mathrm{CDH} 23$}

To understand the mechanism of the $P c d h 15^{\text {noddy }}$ mutation, we performed a series of structural and biochemical analyses in vitro. The I108N mutation replaces a large hydrophobic isoleucine side
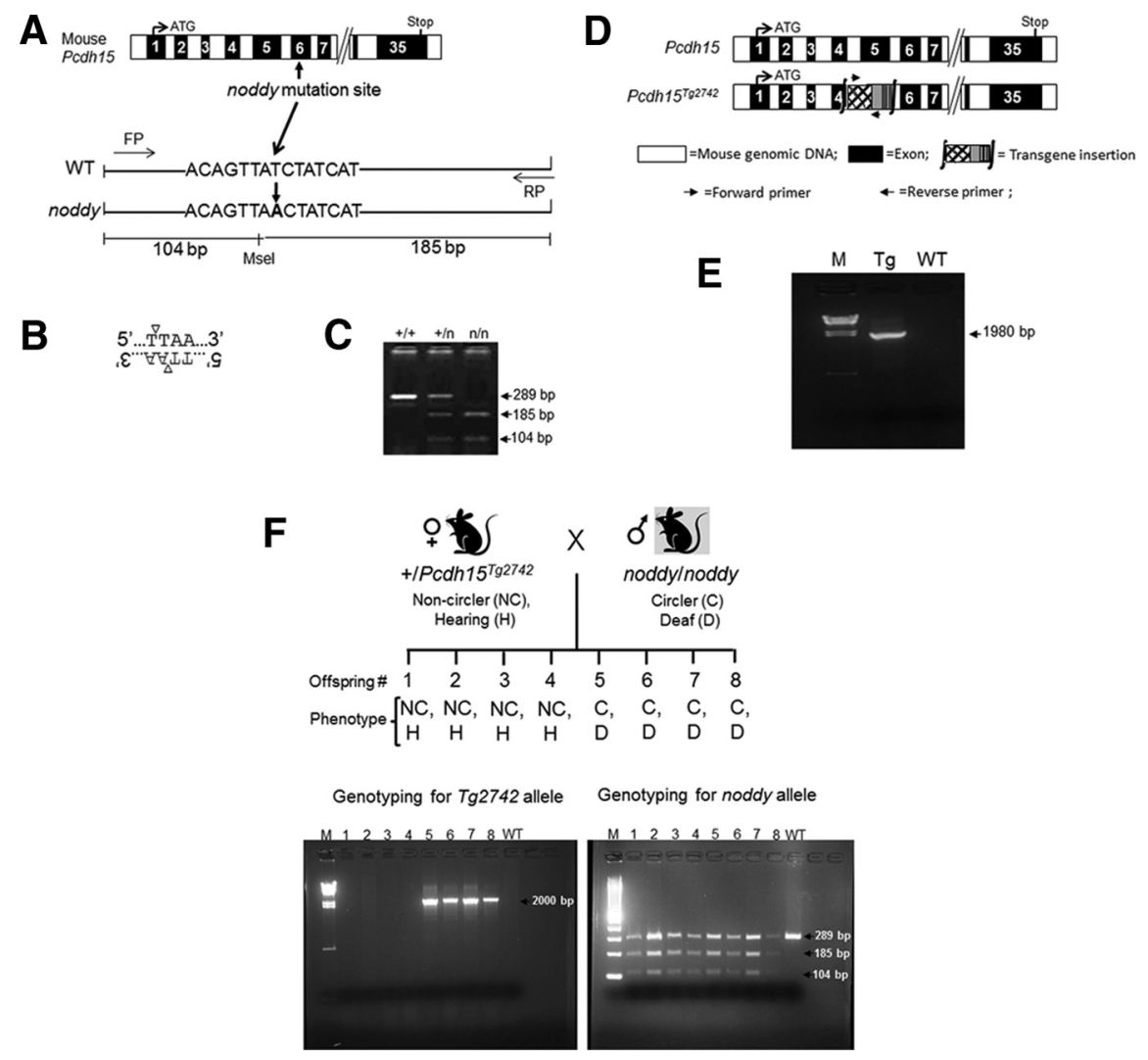

Figure 2. Confirmation of allelism to $P$ cdh15. A, Schematic diagram showing point mutation in exon 6 of $P c d h 15$ in noddy mutant mice. The Noddy mutation introduces a Msel restriction endonuclease site, as shown in the expanded view of the noddy ( Positions of forward primer (FP) and reverse primer (RP) used for genotyping are indicated. $\boldsymbol{B}$, Msel restriction 列 (the site of insertion and serves as a unique sequence (or "tag") to identify the mouse carrying the tation analysis. Mice heterozygous for the $P c d h 15^{T 2} 2742$ allele were mated with mice homozygous for the noddy mutation. A litter of 8 from one of those crosses is shown here. Mice with either normal or noddy behavior were identified in this litter. Genotyping confirmed that all mice with the phenotype carried both alleles, namely, the compound heterozygous genotype (noddy/ $P\left(d h 15^{T g 2742}\right.$ ). Mice 5- 8 are positive for the transgene (left panel) and the noddy allele (right panel). In contrast, mice 1-4 are negative for the transgene (left panel) and positive for the noddy allele (right panel). Both the wild-type and transgenic (nonfunc (289 bp) in all offspring (right panel); offspring also inherits one noddy allele from the male, hence the appearance of noddy mutant bands (189 and 104 bp) in all lanes as well (right panel). Mice showing phenotype carry two nonfunctional copies of $P c d h 15$, resulting in noncomplementation, whereas mice showing normal behavior carry at least one functional/wild-type allele of $P c d h 15$.

chain with a polar asparagine. The mutation might generally impair proper folding, making PCDH15 unavailable for tip-link formation, or could impair protein function more specifically by preventing its binding to $\mathrm{CDH} 23$.

To test folding, we produced a recombinant PCDH15 EC1 + EC2 fragment bearing the I108N mutation. PCDH15 EC1 + EC2 I108N behaved just like the wild-type protein during the refolding and purification step, and the refolded mutant protein had an elution profile equivalent to that observed for the wild-type fragment in SEC experiments (data not shown). In addition, the CD spectrum of the I108N mutant fragment (Fig. $3 A$ ) is very similar to that of the wild-type protein, and both correspond well to that of a properly folded cadherin with antiparallel $\beta$ strands (Prasad and Pedigo, 2005). Thermostability assays using both CD (data not shown) and the thermofluor method (Fig. $3 A$, inset) (Niesen et al., 2007) yielded well-defined melting temperatures (WT: 
A
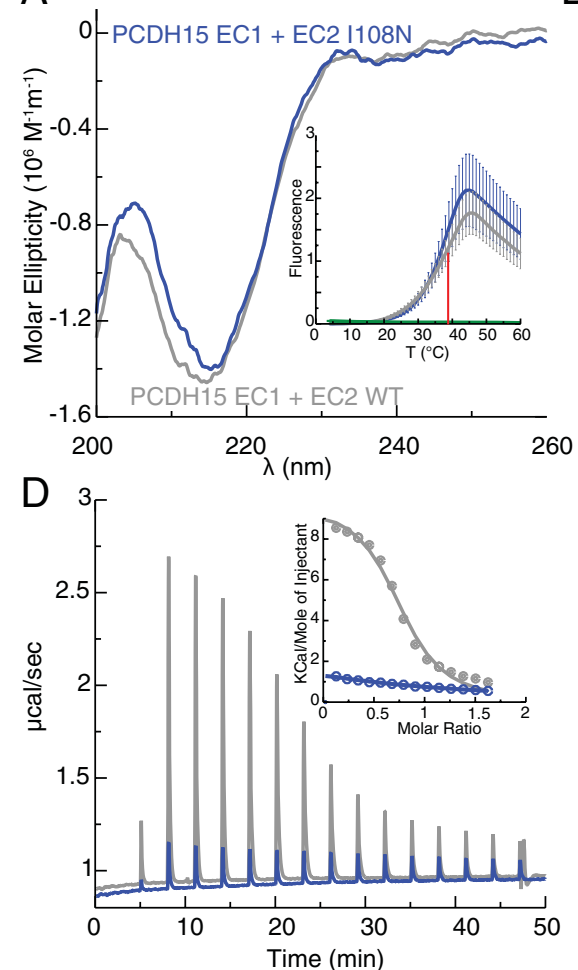

B

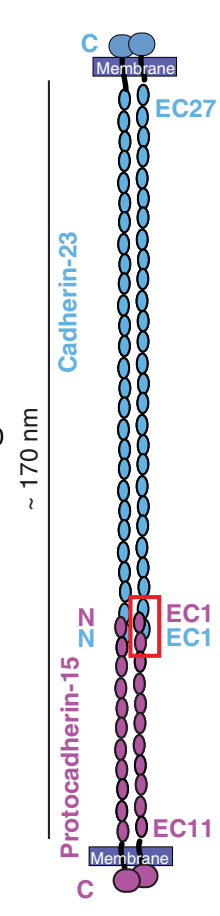

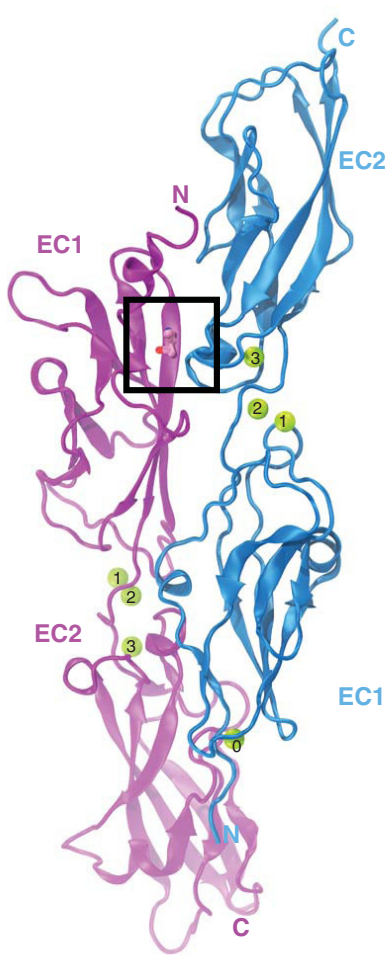
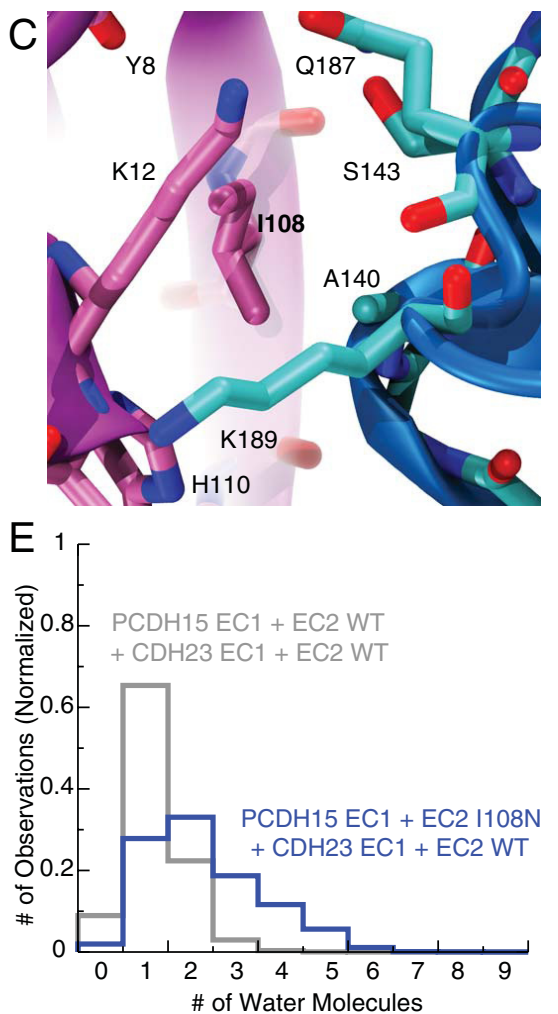

Figure 3. Effect of the I108N mutation on the structure of PCDH15 and its interaction with CDH23. A, Circular dichroism spectra of the refolded wild-type (gray) and I108N (blue) PCDH15 EC1 + EC2 fragments. Inset, Thermostability assay for the same fragments (gray, wild-type; blue, I108N; green, buffer control), with data shown as average of triplicates \pm SD. Red bar represents melting temperature. Spectra and melting data indicate proper folding of both fragments. B, Schematic of cadherin tip link (left) and ribbon diagram (right) of PCDH15 EC1 + EC2 (purple) and CDH23 EC1 + EC2 (blue). Red box indicates location of the cadherin handshake shown in ribbon. Residue I108 of PCDH15 is shown in stick representation, and $C a^{2+}$ ions are shown as green spheres. $C$, Detail of PCDH15's I108 and neighboring residues, from black box in B. (See structure file pdb 4APX; Sotomayor et al., 2012). D, Raw power versus time in ITC experiments for wild-type (gray) and I108N (blue) PCDH15EC1 + EC2, titrated with $\mathrm{CDH} 23 \mathrm{EC} 1+\mathrm{EC} 2$ at $10^{\circ} \mathrm{C}$. Inset, Change in molar enthalpy. The decreased enthalpy change and the lack of saturation indicate impaired interaction between PCDH15EC1 + EC2 I108N and CDH23EC1 + EC2.E, Normalized histograms of the number of water molecules within $5 \AA$ of I 108 (gray) and I108N (blue) C $\alpha$ atoms, from microsecond-long molecular dynamics simulations of the complex. More water is within the interface with the mutation.

$\left.40.3 \pm 0.5^{\circ} \mathrm{C} ; \mathrm{I} 108 \mathrm{~N}: 38.3 \pm 0.5^{\circ} \mathrm{C}\right)$. Thus, the mutation does not seem to significantly affect the protein fold.

We then considered the structure of wild-type PCDH15 EC1 + EC2 bound to CDH23 EC1 + EC2 (Sotomayor et al., 2012). Residue $\mathrm{I} 108$ is at the surface of PCDH15 and is part of the interface between PCDH15 and CDH23 (Fig. 3 B, C). The large hydrophobic isoleucine side chain flanks a disulfide bond at the tip of PCDH15 EC1. It is part of the hydrophobic core of the interface, surrounded by residues Y8, K12, T106 (not in view), and H110 of PCDH15, and by residues G139, A140, S143, Q187, and K189 of $\mathrm{CDH} 23$ (Fig. $3 C$ ). The structure therefore suggests that the I108N mutation could affect PCDH15's ability to bind to CDH23 and thereby destabilize tip-link connections between stereocilia.

To test this hypothesis, we used SEC and ITC to compare the interaction of both wild-type and mutant PCDH15 EC1 + EC2 fragments with CDH23 EC1 + EC2. We observed lack of binding in SEC experiments with the mutant fragment (data not shown). In addition, ITC experiments (Fig. 3D) showed decreased enthalpic heats and lack of saturation with the PCDH15 fragment carrying the $1108 \mathrm{~N}$ mutation, which suggests impaired binding. The enthalpic heats observed here are significantly smaller than those observed under similar conditions for the human PCDH15 R113G deafness mutation (Sotomayor et al., 2012), suggesting that the I108N mutation has a more dramatic effect on the interaction between PCDH15 and CDH23.

Replacement of isoleucine's bulky hydrophobic side chain by the slightly smaller and hydrophilic asparagine side chain could break specific van der Waals contacts, increase hydration at the interface, or both. To elucidate the underlying molecular mechanisms of impaired binding, we performed molecular dynamics simulations of a model of the complex with the mutation (Sotomayor et al., 2010, 2012). During the simulations, more water molecules were observed within the interface than in wild-type (Fig. 3E). The hydrophilic character of the asparagine favors increased hydration of the interface, which may either prevent formation of the complex or promote rupture once formed. Together, the experimental and computational results strongly suggest that the $1108 \mathrm{~N}$ mutation severely impairs binding between PCDH15 and CDH23.

\section{Loss of bundle integrity in Pcdh15 ${ }^{\text {noddy }}$ homozygotes}

To test the consequences of blocking the handshake interaction in vivo, we examined hair bundles by light and electron microscopy in Pcdh $15^{\text {noddy }}$ homozygotes. Scanning electron microscopy of heterozygote and homozygote neonatal hair cells (Fig. 4A-E) revealed disorganized hair bundles in both inner and outer hair cells of Pcdh15 $5^{\text {noddy }}$ homozygotes (Fig. $4 A, B$ ), which was observed also by light microscopy (Fig. $5 A, B$ ). At postnatal day 3 (P3), bundles were misoriented (Fig. 4B), were fragmented into smaller clumps of stereocilia (Fig. $4 D$ ), showed abnormal row structure (Fig. 4E), and had abnormally positioned kinocilia compared with heterozygote controls (Fig. 4C, D, letter "K"). These defects are very similar to those reported for the presumptive null allele Pcdh15 ${ }^{\text {av3J }}$ (Alagramam et al., 2001a, 2001b; Paw- 
lowski et al., 2006; Kikkawa et al., 2008), suggesting that the Pcdh $15^{\text {noddy }}$ mutation is in some respects as severe as a null mutation. The defects become more severe within a few days of development; at P10, the heterozygote showed virtually normal ranking of stereocilia (Fig. $4 F, G$ ), whereas the mutant showed disorder in both position and height of the different rows (Fig. $4 H-J)$.

Perhaps this missense mutation affects protein stability or normal localization of PCDH15, rather than creating a specific functional deficit in an otherwise wellfolded and stable protein. Thus, we used immunocytochemistry to determine whether PCDH15-I108N is degraded or mistargeted in hair cells. Organs of Corti harvested from wild-type and Pcdh $15^{\text {noddy }}$ homozygotes at P3 were stained with PB811, an antibody specific for the amino acid sequence LSLKDNVDYWVLLDPVK (Kazmierczak et al., 2007), which is 37 amino acids upstream of I108. In both wildtype and $P c d h 15^{\text {noddy }}$ homozygote bundles, PB811 labeled the tips of stereocilia of both inner and outer hair cells (Fig. 5C, E). Lack of bundle labeling in the presumptive null allele $P c d h 15^{a v 3 J}$ confirmed the specificity of PB811 (Fig. 5D). Close examination of hair bundles in Pcdh15 ${ }^{\text {noddy }}$ homozygotes shows that PCDH15 is concentrated at the tips of stereocilia (Fig. 5F,G), even though the bundles were fragmented, suggesting that the observed phenotype is not the result of loss of PCDH15 expression or localization. Instead, the $1108 \mathrm{~N}$ mutation apparently produces a specific deficit in the function of EC1.

\section{Pcdh15 ${ }^{\text {noddy }}$ homozygotes fail to develop normal tip links}

Early in hair-bundle development, numerous links connect stereocilia to each other (Furness et al., 1989; Michel et al., 2005). As bundles mature, links segregate into horizontal top connectors, which run horizontally between all adjacent stereocilia, and tip links, which run nearly vertically from shorter to taller stereocilia along the excitatory axis. At P3, control mice formed normal tip links, whereas Pcdh $15^{\text {noddy }}$ homozygotes, in contrast, had links between stereocilia but rarely any that could be described as bona fide tip links (data not shown). To make sure that no true tip links form in these mice, we examined older animals (P10) for tip links, where the heterozygote showed clearly identifiable tip links (Fig. 4G). These were completely absent in the homozygote (Fig. $4 J$ ). Thus, tip links in Pcdh15 noddy homozygote mice were absent.

\section{Pcdh15 ${ }^{\text {noddy }}$ homozygotes lack FM1-43 uptake}

In the absence of tip links, $P c d h 15^{\text {noddy }}$ homozygotes should show loss of mechanotransduction. The amphipathic styryl dye, FM1$G, J, 400 \mathrm{~nm}$
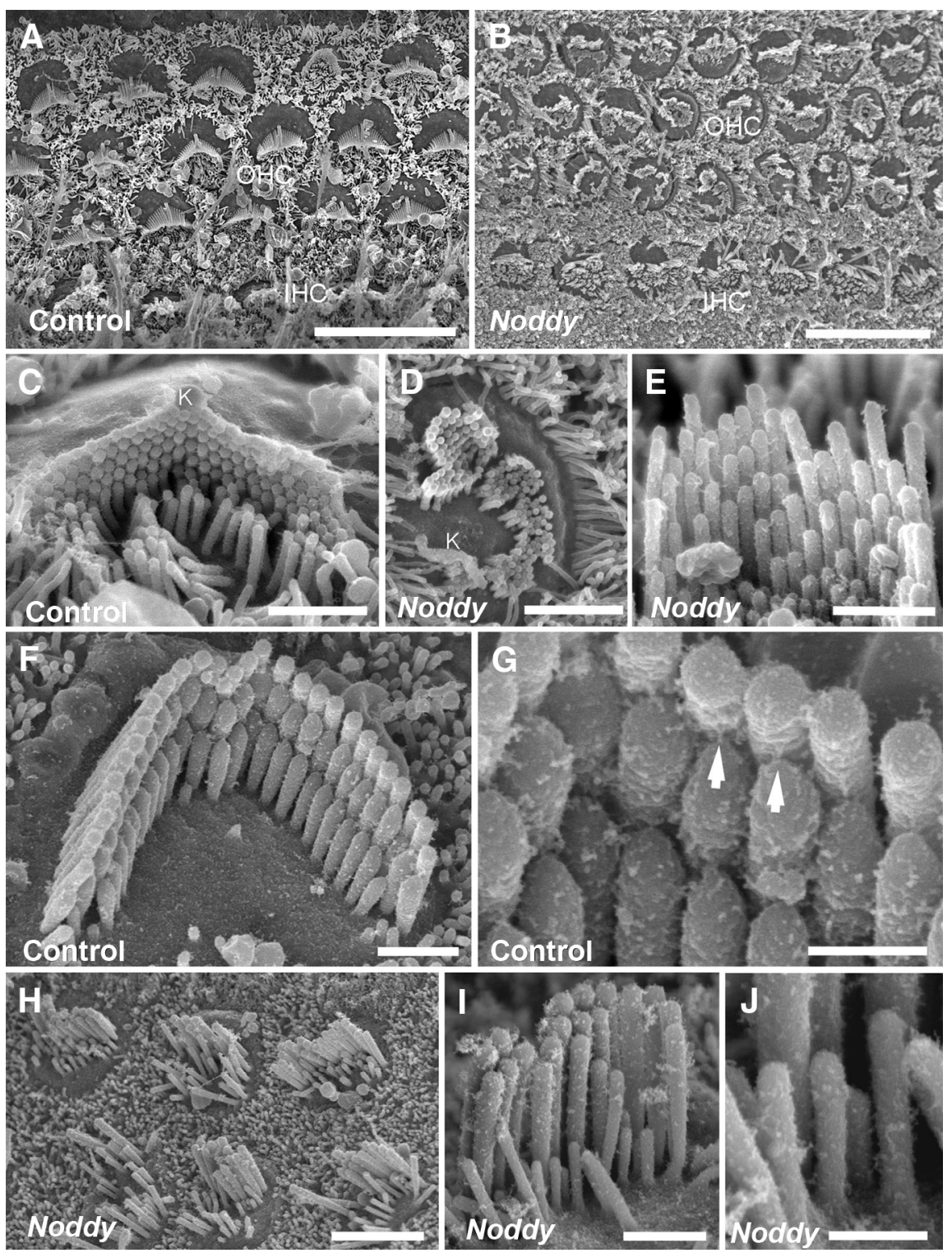

Figure 4. Scanning electron microscopy of hair cells from heterozygous (control) and noddy mice at $\mathrm{P} 3(\boldsymbol{A}-\boldsymbol{E})$ and $\mathrm{P} 10(\boldsymbol{F}-\boldsymbol{J})$. $\boldsymbol{A}$, $B$, Low-power examination of $\mathrm{P3}$ controls showed normally oriented hair bundles in all rows of outer hair cells ( $\mathrm{OHC}$ ) and in inner hair cells $(\mathrm{IHC})$, whereas in noddy, bundles were both fragmented and misoriented. $C$, Higher-power examination of single $\mathrm{P} 3 \mathrm{OHC}$ bundles from controls revealed the typical $V$-shaped bundle with rows of stereocilia organized in graded heights and a kinocilium at the vertex (letter " $K$ "). D, In the P3 noddy cochleae, the V shape was disrupted and the bundle fragmented into clumps associated with abnormally positioned kinocilia (letter " $K^{\prime \prime)}$. E, The stereociliary row structure was abnormal in noddy $0 H(S . F, G$, at P10, the control specimens showed well-ordered hair bundles with few defects in row structure and well-defined tip links (arrows). $\boldsymbol{H}-\boldsymbol{J}_{\boldsymbol{i}}$ ow-power examination of P10 noddy specimen showed that bundles were both fragmented and misoriented $(\boldsymbol{H})$, the row structure in $\mathrm{OHC}$ bundles was disordered and tip links could not be identified (I,J). Scale bars: $A, B, 10 \mu \mathrm{m} ; \boldsymbol{C}-\boldsymbol{F}, \boldsymbol{I}, 1 \mu \mathrm{m} ; \boldsymbol{H}, 4 \mu \mathrm{m}$;

43 , is known to enter hair cells via mechanotransduction channels that are partially open at rest. Because resting tip-link tension is required to keep the channels partially open, lack or loss of tip links prevents rapid internalization of FM1-43 (Gale et al., 2001; Meyers et al., 2003). We examined cochlear cultures from wildtype and $P c d h 15^{\text {noddy }}$ homozygotes for their ability to load with FM1-43 in response to a brief (10 s) exposure to the dye. Hair cells from control mice showed dye loading in the apical and basal turn as expected (Fig. 6A,E). In contrast, hair cells from the $P c d h 15^{\text {noddy }}$ homozygotes did not load with FM1-43 dye in any turn of the cochlea (Fig. $6 B, F$ ) indicating that mechanotransduction channels are closed at rest. The same was reported for the 

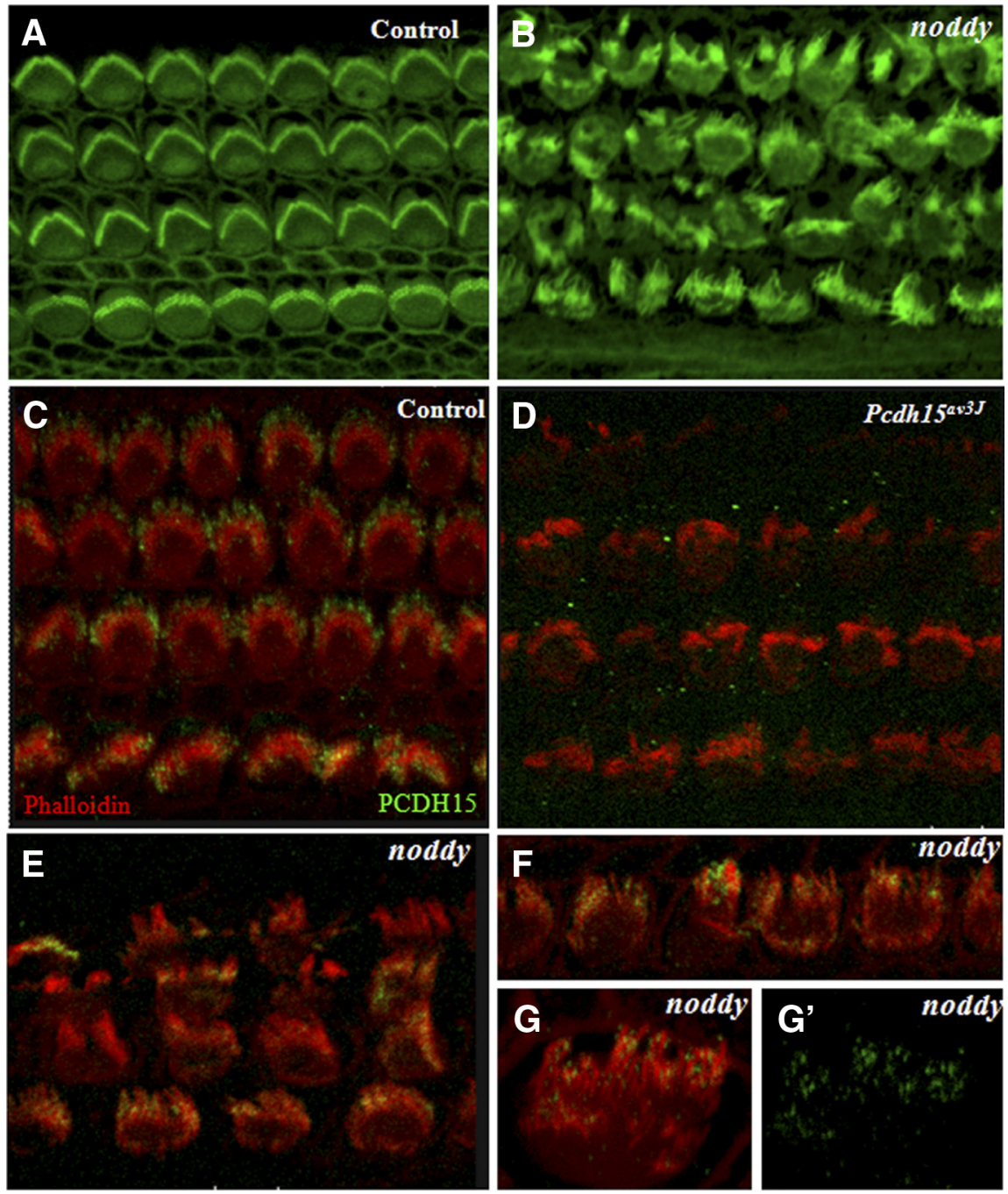

Figure 5. Hair bundle morphology and PCDH15 expression in noddy homozygote hair cells at $\mathrm{P} 3 . \boldsymbol{A}, \boldsymbol{B}$, Outer and inner cochlear hair cells in noddy heterozygotes (control) $(\boldsymbol{A})$ and noddy homozygotes (noddy) mice $(\boldsymbol{B})$, stained with phalloidin (green). Both inner and outer hair cell bundles in the homozygotes were severely disrupted in P3 hair cells. $\mathbf{C}-\mathbf{G}$, Cochlear hair cells stained with the PCDH15 EC1-specific polyclonal antibody PB811 (green) and phalloidin (red). PCDH15 protein is near the tips of stereocilia in control $(\boldsymbol{C})$ and noddy homozygotes $\left(\boldsymbol{E}-\mathbf{G}, \mathbf{G}^{\prime}\right)$, but not in the bundle of the av3J presumptive null allele of $P C D H 15$ (D). Close-up view of a single outer hair cell bundle from a Pcdh15 stained with PCDH15 antibody shows labeling at the tips of the stereocilia $\left(\mathbf{G}, \mathbf{G}^{\prime}\right)$. To detect residual staining for PCDH15 in the av3J bundle, a higher gain setting was used for the green channel, but no staining was found in the bundle $(\boldsymbol{D})$, validating the specificity of PB811 for PCDH15. The few green dots observed outside of the bundle and on supporting cells represent nonspecific background.

presumptive null allele of $P c d h 15\left(P c d h 15^{a v 3 J}\right)$, which also lacked clearly identifiable tip links and transducer currents (Alagramam et al., 2011). Therefore, the I108N mutation apparently affects the ability of PCDH15 to form links with $\mathrm{CDH} 23$ in vivo as well as in vitro.

\section{Discussion}

We first reported that PCDH15 is essential for hearing and balance in the mouse and specifically for normal development of hair bundles (Alagramam et al., 2001a, 2001b; Pawlowski et al., 2006; Kikkawa et al., 2008). More recently, we showed that an in-frame deletion of 47 amino acids in EC9 of PCDH15 (associated with the av6J allele of Pcdh15 in the mouse) does not prevent formation of tip links, although the av6J links are apparently not stable over time (Alagramam et al., 2011). Similarly, a missense mutation in EC7 of mouse CDH23 does not affect the formation noddy

of tip links, although they are progressively lost (Schwander et al., 2009). In contrast, Pcdh15 ${ }^{\text {noddy }}$ homozygotes show that a point mutation in EC1 of PCDH15 disrupts bundle integrity, much like the null allele $P c d h 15^{\text {av3J }}$. The hair bundle arrangement at P3 in Pcdh15 $5^{\text {noddy }}$ homozygotes was severely disrupted and misoriented; the kinocilia were often abnormally positioned as well. PCDH15 I108N was expressed in the hair bundle in Pcdh15 noddy homozygotes, but tip links did not form; thus, the observed phenotype is likely the result of impaired interaction with its partner, $\mathrm{CDH} 23$, rather than degradation or mislocalization of the mutant protein.

Data presented here and the phenotypic similarity to the $P c d h 15^{a v-3 J}$ mice (Alagramam et al., 2011) suggest that noddy homozygotes lack mechanotransduction. Both noddy and Pcdh15 ${ }^{a v-3 J}$ homozygotes failed to (1) develop normal tip links, (2) develop normal bundle morphology, and (3) load FM1-43. In contrast to controls, hair cells of Pcdh15 ${ }^{\text {av3J }}$ homozygotes have links between stereocilia but rarely with the stereotypical alignment along the excitatory axis from short to tall. Hair cells from $P c d h 15^{a v-3 J}$ mice fail to produce normal mechanotransduction currents in response to fluid-jet stimulation, indicating that the observed links are not bona fide tip links. Because the hair cell phenotype in the noddy homozygote is a phenocopy of the defects observed in Pcdh15 ${ }^{a v-3 J}$ mutant (points 1-3 above), it is likely that mechanotransduction is impaired in noddy mutant hair cells as well.

The hair bundle phenotypes in $P c d h 15^{a v 3 J}$ and $P c d h 15^{\text {noddy }}$ indicate that loss of PCDH15 function affects normal hair bundle development concomitant with lack of tip link formation in mouse cochlear hair cells. We hypothesize that, in addition to its role in the tip links, PCDH15 and CDH23 in mouse cochlear hair cells also serve as key components of interciliary links, including kinocilial links. These interciliary links might be essential for bundle cohesion and for the polarized, V-shaped arrangement of the bundle with the kinocilia at the vertex. There is some support for this idea. Using immunogold labeling in vestibular hair cells of chicken, Goodyear et al. (2010) showed that the kinociliary links are made of PCDH15 and $\mathrm{CHD} 23$ proteins, that $\mathrm{CDH} 23$ localizes to the stereocilium, and that PCDH15 localizes to the kinocilium. Therefore, it is conceivable that loss of the PCDH15-CDH23 interaction in the mouse cochlear hair bundle causes the loss of bundle cohesion and orientation.

In previous studies based on the crystal structure of $\mathrm{CDH} 23$ $\mathrm{EC} 1+\mathrm{EC} 2$, it was proposed that $\mathrm{CDH} 23$ interacts with PCDH15 via a calcium-binding site created by polar residues at the tips of 
EC1 of both proteins (Sotomayor et al., 2010; Elledge et al., 2010). Through cocrystallization of the proteins, we instead discovered an extended "handshake" interface linking EC1 + EC2 of CDH23 and PCDH15 (Fig. 3B) (Sotomayor et al., 2012). Structural analyses reported here provide further support for this interface and demonstrate that $\mathrm{I} 108$ of PCDH15 is in a critical part of the binding interface between the EC1 domain of PCDH15 and the EC2 domain of CDH23. The PCDH15-I108N mutation in Pcdh15 $15^{\text {noddy }}$ mutant mice shows that residues more distal from the extreme tip of EC1 are important for binding. The in vivo and complementary in vitro data presented here further support an extended binding interface between PCDH15$\mathrm{CDH} 23 \mathrm{EC} 1$ and EC2.

The extended binding interface model is consistent with the unique requirements for cadherin binding in the inner ear. It is likely that tip links endure greater mechanical stress resulting from loud sound stimuli than do classic cadherins at cell-cell junctions. The extended interface might create a tip-link bond that is mechanically stronger than that proposed for a single $\mathrm{Ca}^{2+}$ binding site at the tip of EC1. Indeed, steered molecular dynamics simulations forcing unbinding of the PCDH15 and CDH23 complex suggest that the heterophilic bond is mechanically stronger than that of a typical homophilic C-cadherin bond (Sotomayor et al., 2012).

The data presented here also highlight the variety of phenotypes and molecular mechanisms associated with deleterious mutations in PCDH15 and $\mathrm{CDH} 23$. Although many mutations in human $\mathrm{CDH} 23$ and PCDH15 replace canonical calcium-binding residues (de Brouwer et al., 2003), the Pcdh15 ${ }^{\text {noddy }}$ mutation impairs binding but does not modify a residue in or near any of the calcium-binding domains (Fig. 1C). Thus, the interaction between PCDH15 and $\mathrm{CDH} 23$ can be affected by mutations in amino acids not involved in calcium binding. Pcdh1 $15^{\text {noddy }}$ mice may serve as a good model for the human PCDH15-R113G mutation (reported as R139G, including the signal sequence) (Ahmed et al., 2003), which is similarly located in EC1 but not at calciumbinding sites. The PCDH15-R113G mutation impairs binding in vitro of full-length PCDH15 to CDH23 (Kazmierczak et al., 2007), and it inhibits binding of PCDH15 protein fragments to tip links in cochlear cultures (Lelli et al., 2010). The lack of a vestibular phenotype for PCDH15-R113G is consistent with a more dramatic effect of the $P c d h 15^{\text {noddy }}$ mutation on the interaction between PCDH15 and CDH23 in in vitro ITC experiments (Sotomayor et al., 2012).

In contrast, the zebrafish PCDH15-V116Q mutation in EC1 (reported as V142Q, including signal sequence) causes severe auditory and vestibular phenotypes by modifying a residue close to the calcium-binding domain of PCDH15 EC1 + EC2 (Seiler et al., 2005). This mutation might impair folding or decrease calcium-binding affinity. Similarly, the salsa mu- tation E737V directly modifies a calcium-binding residue in EC7 of CDH23 and shows only progressive hearing loss and gradual loss of tip links over time (Schwander et al., 2009). Other mutations in human CDH23 affecting calcium-binding sites produce a similar phenotype (Bork et al., 2001; Pennings et al., 2004; Wagatsuma et al., 2007; de Brouwer et al., 2003).

Recently, a mouse carrying a mutation in the EC1 domain of CDH23 was reported (Han et al., 2012). This CDH23-S47P mutation results in hearing loss, consistent with the idea that, like the EC1 domain of PCDH15, the EC1 domain of $\mathrm{CDH} 23$ is important for the tip-link interaction. However, the CDH23-S47P mutation is not located at the "handshake" interface, it does not impair PCDH15CDH23-S47P binding in vitro (Sotomayor et al., 2012), and it causes a much milder phenotype than the I108N mutation in PCDH15 EC1. Specifically, the CDH23-S47P mutation causes late-onset hearing loss (starting at P27) without obvious vestibular dysfunction. The more dramatic effect of the PCDH15-I108N mutation supports the idea that the $\mathrm{I} 108$ residue of PCDH15 is in a critical part of the binding interface. This rich repertoire of molecular mechanisms and phenotypes suggests that many specific animal models are required to understand diseases associated with missense mutations in $\mathrm{PCDH} 15$ and $\mathrm{CDH} 23$. Noddy mutant mice provide a unique in vivo model for understanding the consequences of mutations to the tiplink binding interface. 
In conclusion, data presented here reveal the pathogenic mechanism underlying the Pcdh $15^{\text {noddy }}$ mutation in PCDH15 and important properties of the interaction between PCDH15 and $\mathrm{CDH} 23$, critical for hearing and balance. The noddy mouse is also the first mouse model for missense mutations that directly affect PCDH15 and $\mathrm{CDH} 23$ binding, and in this context may emerge as a tool to explore molecular therapies.

\section{References}

Ahmed ZM, Riazuddin S, Bernstein SL, Ahmed Z, Khan S, Griffith AJ, Morell RJ, Friedman TB, Riazuddin S, Wilcox ER (2001) Mutations of the protocadherin gene PCDH15 cause Usher syndrome type 1F. Am J Hum Genet 69:25-34. CrossRef Medline

Ahmed ZM, Riazuddin S, Ahmad J, Bernstein SL, Guo Y, Sabar MF, Sieving P, Riazuddin S, Griffith AJ, Friedman TB, Belyantseva IA, Wilcox ER (2003) PCDH15 is expressed in the neurosensory epithelium of the eye and ear and mutant alleles are responsible for both USH1F and DFNB23. Hum Mol Genet 12:3215-3223. CrossRef Medline

Ahmed ZM, Goodyear R, Riazuddin S, Lagziel A, Legan PK, Behra M, Burgess SM, Lilley KS, Wilcox ER, Riazuddin S, Griffith AJ, Frolenkov GI, Belyantseva IA, Richardson GP, Friedman TB (2006) The tip-link antigen, a protein associated with the transduction complex of sensory haircells, is protocadherin-15. Neurosci 26:7022-7034. CrossRef Medline

Alagramam KN, Kwon HY, Cacheiro NL, Stubbs L, Wright CG, Erway LC, Woychik RP (1999) A new mouse insertional mutation that causes sensorineural deafness and vestibular defects. Genetics 152:1691-1699. Medline

Alagramam KN, Murcia CL, Kwon HY, Pawlowski KS, Wright CG, Woychik RP (2001a) The mouse Ames waltzer hearing-loss mutant is caused by mutation of Pcdh15, a novel protocadherin gene. Nat Genet 27:99-102. CrossRef Medline

Alagramam KN, Yuan H, Kuehn MH, Murcia CL, Wayne S, Srisailpathy CR, Lowry RB, Knaus R, Van Laer L, Bernier FP, Schwartz S, Lee C, Morton CC, Mullins RF, Ramesh A, Van Camp G, Hageman GS, Woychik RP, Smith RJ (2001b) Mutations in the novel protocadherin PCDH15 cause Usher syndrome type 1F. Hum Mol Genet 10:17091718. CrossRef Medline

Alagramam KN, Goodyear RJ, Geng R, Furness DN, van Aken AF, Marcotti W, Kros CJ, Richardson GP (2011) Mutations in protocadherin 15 and cadherin 23 affect tip links and mechanotransduction in mammalian sensory hair cells. PLoS One 6:e19183. CrossRef Medline

Beurg M, Fettiplace R, Nam JH, Ricci AJ (2009) Localization of inner hair cell mechanotransducer channels using high-speed calcium imaging. Nat Neurosci 12:553-558. CrossRef Medline

Bork JM, Peters LM, Riazuddin S, Bernstein SL, Ahmed ZM, Ness SL, Polomeno R, Ramesh A, Schloss M, Srisailpathy CR, Wayne S, Bellman S, Desmukh D, Ahmed Z, Khan SN, Kaloustian VM, Li XC, Lalwani A, Riazuddin S, Bitner-Glindzicz M, et al. (2001) Usher syndrome 1D and nonsyndromic autosomal recessive deafness DFNB12 are caused by allelic mutations of the novel cadherin-like gene CDH23. Am J Hum Genet 68:26-37. CrossRef Medline

Brasch J, Harrison OJ, Honig B, Shapiro L (2012) Thinking outside the cell: how cadherins drive adhesion. Trends Cell Biol 22:299-310. CrossRef Medline

de Brouwer AP, Pennings RJ, Roeters M, Van Hauwe P, Astuto LM, Hoefsloot LH, Huygen PL, van den Helm B, Deutman AF, Bork JM, Kimberling WJ, Cremers FP, Cremers CW, Kremer H (2003) Mutations in the calciumbinding motifs of cdh23 and the 35delG mutation in GJB2 cause hearing loss in one family. Hum Genet 112:156-163. Medline

Di Palma F, Holme RH, Bryda EC, Belyantseva IA, Pellegrino R, Kachar B, Steel KP, Noben-Trauth K (2001) Mutations in Cdh23, encoding a new type of cadherin, cause stereocilia disorganization in waltzer, the mouse model for Usher syndrome type 1D. Nat Genet 27:103-107. CrossRef Medline

Elledge HM, Kazmierczak P, Clark P, Joseph JS, Kolatkar A, Kuhn P, Müller U (2010) Structure of the $\mathrm{N}$ terminus of cadherin 23 reveals a new adhesion mechanism for a subset of cadherin superfamily members. Proc Natl Acad Sci U S A 107:10708-10712. CrossRef Medline

Furness DN, Hackney CM (1985) Cross-links between stereocilia in the guinea pig cochlea. Hear Res 18:177-188. CrossRef Medline

Furness DN, Richardson GP, Russell IJ (1989) Stereociliary bundle mor- phology in organotypic cultures of the mouse cochlea. Hear Res 38: 95109. CrossRef Medline

Furness DN, Katori Y, Nirmal Kumar B, Hackney CM (2008) The dimensions and structural attachments of tip links in mammalian cochlear hair cells and the effects of exposure to different levels of extracellular calcium. Neuroscience 154:10-21. CrossRef Medline

Gale JE, Marcotti W, Kennedy HJ, Kros CJ, Richardson GP (2001) FM1-43 dye behaves as a permeant blocker of the hair-cell mechanotransducer channel. J Neurosci 21:7013-7025. Medline

Gillespie PG, Müller U (2009) Mechanotransduction by hair cells: models, molecules, and mechanisms. Cell 139:33-44. CrossRef Medline

Goodyear RJ, Forge A, Legan PK, Richardson GP (2010) Asymmetric distribution of cadherin 23 and protocadherin 15 in the kinocilial links of avian sensory hair cells. J Comp Neurol 518:4288-4297. CrossRef Medline

Hampton LL, Wright CG, Alagramam KN, Battey JF, Noben-Trauth K (2003) A new spontaneous mutation in the mouse Ames waltzer gene, Pcdh15. Hear Res 180:67-75. CrossRef Medline

Han F, Yu H, Tian C, Chen HE, Benedict-Alderfer C, Zheng Y, Wang Q, Han $X$, Zheng QY (2012) A new mouse mutant of the Cdh23 gene with earlyonset hearing loss facilitates evaluation of otoprotection drugs. Pharmacogenomics J 12:30-44. CrossRef Medline

Hardisty-Hughes RE, Parker A, Brown SD (2010) A hearing and vestibular phenotyping pipeline to identify mouse mutants with hearing impairment. Nat Protoc 5:177-190. CrossRef Medline

Humphrey W, Dalke A, Schulten K (1996) VMD: visual molecular dynamics. J Mol Graphics 14:33-38. CrossRef Medline

Kazmierczak P, Sakaguchi H, Tokita J, Wilson-Kubalek EM, Milligan RA, Müller U, Kachar B (2007) Cadherin 23 and protocadherin 15 interact to form tip-link filaments in sensory hair cells. Nature 449:87-91. CrossRef Medline

Kikkawa YS, Pawlowski KS, Wright CG, Alagramam KN (2008) Development of outer hair cells in Ames waltzer mice: mutation in protocadherin 15 affects development of cuticular plate and associated structures. Anat Rec 291:224-232. CrossRef Medline

Lelli A, Kazmierczak P, Kawashima Y, Müller U, Holt JR (2010) Development and regeneration of sensory transduction in auditory hair cells requires functional interaction between cadherin-23 and protocadherin- 15 . J Neurosci 30:11259-11269. CrossRef Medline

Meyers JR, MacDonald RB, Duggan A, Lenzi D, Standaert DG, Corwin JT, Corey DP (2003) Lighting up the senses: FM1-43 loading of sensory cells through nonselective ion channels. J Neurosci 23:4054-4065. Medline

Michel V, Goodyear RJ, Weil D, Marcotti W, Perfettini I, Wolfrum U, Kros CJ, Richardson GP, Petit C (2005) Cadherin 23 is a component of the transient lateral links in the developing hair bundles of cochlear sensory cells. Dev Biol 280:281-294. CrossRef Medline

Niesen FH, Berglund H, Vedadi M (2007) The use of differential scanning fluorimetry to detect ligand interactions that promote protein stability. Nat Protocols 2:2212-2221. CrossRef Medline

Parker A, Hardistry-Hughes RE, Wisby L, Joyce S, Brown SD (2010) Melody, an ENU mutation in Caspase-3, alters the catalytic cysteine residue and causes sensorineural hearing loss in mice. Mamm Genome 11:565576. CrossRef Medline

Pawlowski KS, Kikkawa YS, Wright CG, Alagramam KN (2006) Progression of inner ear pathology in Ames waltzer mice and the role of protocadherin 15 in hair cell development. J Assoc Res Otolaryngol 7:83-94. CrossRef Medline

Pennings RJ, Topsakal V, Astuto L, de Brouwer AP, Wagenaar M, Huygen PL, Kimberling WJ, Deutman AF, Kremer H, Cremers CW (2004) Variable clinical features in patients with CDH23 mutations (USH1D-DFNB12). Otol Neurotol 25:699-706. CrossRef Medline

Phillips JC, Braun R, Wang W, Gumbart J, Tajkhorshid E, Villa E, Chipot C, Skeel RD, Kalé L, Schulten K (2005) Scalable molecular dynamics with NAMD. J Comp Chem 26:1781-1802. CrossRef Medline

Pickles JO, Comis SD, Osborne MP (1984) Cross-links between stereocilia in the guinea pig organ of Corti, and their possible relation tosensory transduction. Hear Res 15:103-112. CrossRef Medline

Prasad A, Pedigo S (2005) Calcium-dependent stability studies of domains 1 and 2 of epithelial cadherin. Biochemistry 44:13692-13701. CrossRef Medline

Schwander M, Xiong W, Tokita J, Lelli A, Elledge HM, Kazmierczak P, Sczaniecka A, Kolatkar A, Wiltshire T, Kuhn P, Holt JR, Kachar B, Tarantino L, Müller U (2009) A mouse model for nonsyndromic deafness 
(DFNB12) links hearing loss to defects in tip links of mechanosensory hair cells. Proc Natl Acad Sci U S A 106:5252-5257. CrossRef Medline

Seiler C, Finger-Baier KC, Rinner O, Makhankov YV, Schwarz H, Neuhauss SC, Nicolson T (2005) Duplicated genes with split functions: independent roles of protocadherin 15 orthologues in zebrafish hearing and vision. Development 132:615-623. CrossRef Medline

Shaw DE, Maragakis P, Lindorff-Larsen K, Piana S, Dror RO, Eastwood MP, Bank JA, Jumper JM, Salmon JK, Shan Y, Wriggers W (2010) Atomiclevel characterization of the structural dynamics of proteins. Science 330: 341-346. CrossRef Medline

Sotomayor M, Weihofen WA, Gaudet R, Corey DP (2010) Structural determinants of cadherin-23 function in hearing and deafness. Neuron 66:85100. CrossRef Medline

Sotomayor M, Weihofen, WA, Gaudet R, Corey DP (2012) Structure of a force-conveying cadherin bond essential for inner-ear mechanotransduction. Nature 492:128-132. CrossRef Medline
Wagatsuma M, Kitoh R, Suzuki H, Fukuoka H, Takumi Y, Usami S (2007) Distribution and frequencies of CDH23 mutations in Japanese patients with non-syndromic hearing loss. Clin Genet 72:339-344. CrossRef Medline

Washington JL 3rd, Pitts D, Wright CG, Erway LC, Davis RR, Alagramam K (2005) Characterization of a new allele of Ames waltzer generated by ENU mutagenesis. Hear Res 202:161-169. CrossRef Medline

Woychik RP, Alagramam KN (1998) Insertional mutagenesis in transgenic mice generated by the pronuclear microinjection procedure. Int J Dev Biol. 42:1009-1017. Medline

Zheng QY, Yu H, Washington JL 3rd, Kisley LB, Kikkawa YS, Pawlowski KS, Wright CG, Alagramam KN (2006) A new spontaneous mutation in the mouse protocadherin 15 gene. Hear Res 219:110-120. CrossRef Medline 